Part 1. Pp. 19-37.

\title{
Implication of Tenancy Status on Productivity and Efficiency: Evidence from Fiji
}

\author{
Mahendra Reddy ${ }^{*}$
}

\begin{abstract}
Productivity differences between tenant and owner operated farms have often been investigated using traditional methods. All these studies compute the partial productivity differences between the two farm ownership types. This paper takes the analysis one step further by examining the differences in efficiency among these two farm types. A stochastic frontier production function analysis reveals significant differences between the two farms with respect to input usage, productivity and technical efficiency. Factors causing the differences are identified and policy implications drawn..
\end{abstract}

\section{Introduction}

The recent trend in globalisation has called for efficient utilisation of resources in order to foster the growth and development of the economy. A large number of developing countries has benefited immensely from the preferential treatment that they have received from the developed countries. However, these benefits have also created a number of negative issues which is now being brought to the lime light. Due to the preferential treatments, the push to improve productivity and efficiency has been overshadowed. The rise of free market economic policies is now bringing to the fore these issues.
While some countries have seen merit in such policies, some countries were cautious and thus reluctant to adopt it. However, other factors such as excessive debt burden, were required to change their overall growth strategy in order to qualify for financial assistance from the World Bank and IMF, the proponents of market based policies. These policies are generally referred to as "Structural Adjustment Policies (SAPs)".

One industry that is facing a challenge from the forces of globalisation in Fiji is the Sugar industry. The sugar industry has been the backbone of the Fijian economy for over a century. Since

The author is Senior Lecturer, University of the South Pacific, Suva, Fiji. 
1975, the industry has expanded to its current level with the support of preferential access to the EU, which has been the main importer of Fiji sugar. Around 80-90 per cent of sugar produced is exported, with the EU accounting for 44 per cent on average (within a range of 36-56 per cent during the period 1984-96 of total sugar exports (see Table 1), under the Sugar Protocol of the Lome Convention (hereafter the Lome Convention and since 2000 the Cotonou Agreement). Under this agreement Fiji presently has a quota of 197,000 tones, and prices received are usually two to three times the world market price.

Until the mid-1970s, the UK was the main buyer of Fiji sugar. Following the UK's entry into the European Community (EC) in 1973, Fiji gained access to the wider sugar market of other EC countries under the Lome Convention, including the African, Caribbean and Pacific (ACP) countries. In 1995, the Special Preferential Sugar (SPS) agreement signed between the ACP countries and Portugal, Finland and France came into force, providing Fiji an additional quota of 25,000 tones. SPS prices are linked to the prices received under the Lome convention, which in turn are linked to EU domestic prices. Fiji currently has a quota equivalent to 0.9 per cent of the total US sugar import quota (over the period 1994-96, exports to the US averaged 14,000 tones). The bilateral agreement with Malaysia allows for the export of 90,000 tones of sugar per year.

Fiji's sugar industry is at a crossroads and thus certain important and critical decisions needs to be made (Reddy, 1998). One of these decisions relate to the type of land tenure system that the industry should adopt which would facilitate the move towards increasing productivity and efficiency in the industry at the farm level. Therefore, in this paper, we investigate how different types of tenancy agreements with regard to land can cause differences in productivity and efficiency in Fiji's sugar industry. Land is at the heart of the production mode of agrarian communities, and thus problems relating to land will have a direct impact on their livelihood. While the relationship between land security and productivity has been widely studied, little is known whether the productivity differential is due to inefficient resource allocation or due to the use of less productive resources or both. To date no analysis has been done to explicitly measure the level of inefficiency that may exist for tenant and owner operated farms under the same resource base, government policies, and crop. Lack of such analysis will 
result in weak and inadequate policy implications, which may fall short of achieving the desired goal. This is the first study to investigate the implication of tenancy status on inefficiency utilising a stochastic frontier production function approach.

\section{Tenancy Status and Productivity}

Literature on land tenure has revealed that, as income potential from land increases, the incidence of land disputes and land grabbing, and thus tenure insecurity increases (Clark, 1969; Baron, 1978; Tanabe, 1978; Tomosugi, 1980; Kemp, 1981; Feeny, 1982; Gavian and Fafchamps, 1996). Insecurity with respect to ownership of land has a negative impact on productivity (Feder, 1987; Salas et al., 1970). The primary way ownership security impacts farm productivity is via its effect on the supply of investment capital available to farmers. The impact of ownership security on investment has been widely studied. Among these studies are Salas et al., (1970), Villamizar (1984), Bruce and MigotAdolla (1994), Atwood (1990), Barrows and Roth (1990), Green (1987); Kille and Lyne (1993) and Feder and Onchan (1987). These studies suggests that land title can stimulate investment by means of the collateral (or credit supply) effect.
By turning land into a mortgageable, transferable commodity, farmers can use it as collateral to access the credit needed for productivity enhancing investments. In Fiji, the uncertainty with regard to the renewal of land leases has halted major long-term investments in the industry. These investments will not be made unless a permanent solution is put in place that would provide security to the interests of all parties concerned. With reduced investment in the industry, in particular at the farm level, there will be direct negative implications on productivity. These arise not only from a fall in the supply of productivity enhancing investments, but also from the decline in area under new crop and reduced farm improvements such as drainage and irrigation, and soil conservation and other farm developments.

\section{Overview of Land Tenure in Fiji}

The land tenure system in Fiji is very unique. It is unique in the sense that the agrarian community in Fiji comprises of two ethnic communities, the indigenous Fijians and the migrant Indian labourers. Indians were brought in by colonial rulers to establish the sugar plantations. Upon the departure of the colonial rulers, the Indian labourers chose to remain in Fiji. The departure of the colonial rulers 
led to the rise of major problems in Fiji, one being the debate over land rights. Three basic categories of land are found in Fiji, the native land, freehold land and crown land. Table 1 shows the proportion of land under each category.

The freehold land refers to the alienated land, which had become bona fide property of Europeans and other foreigners. This land is in the market and can be exchanged freely. The crown land refers to land which was not claimed back by the indigenous community after the departure of the colonial rulers. This land is owned by the state and leased out to the public. The native land is the exclusive property of the indigenous community. This land is not in the market and thus cannot be sold. However it can be leased out. The majority of the Fijian-Indian farmers occupy the leased land. In $1989,152,600$ hectares of land was leased out to Indians while the indigenous community leased out 121,300 hectares of land.

Over the years, as Indians continued to benefit from the cultivation of these leased land, the rental rates increased. The rent assessed to Indian farmers were also relative to the indigenous community. Figure 1 reveals the increasing disparity of rent rates among the two farming communities.

Table 1: $\quad$ Land type and proportion in Fiji

\begin{tabular}{lc}
\hline Land Type & Proportion $(\%)$ \\
\hline Native land & 82.5 \\
Crown land & 9.5 \\
Freehold land & 8.0
\end{tabular}

Source: Native Land Trust Board, Government of Fiji. 
Figure 1: $\quad$ Rent per hectare for Indian and Fijian farms, 1982-89.

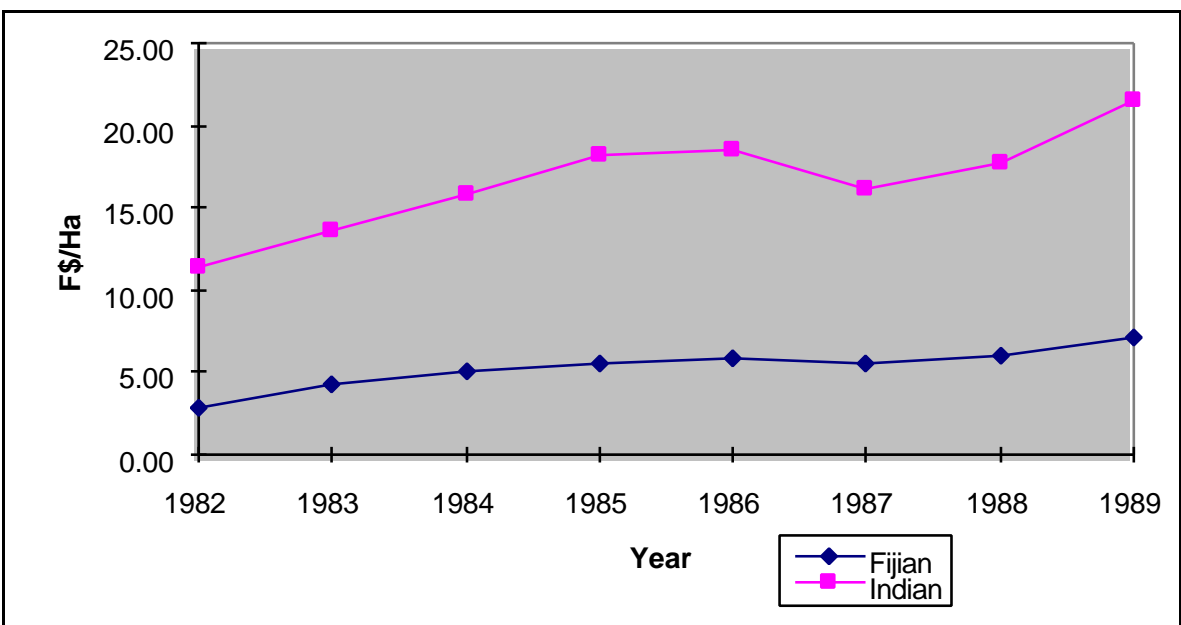

Source: Native Land Trust Board, Government of Fiji.

Indian farmers comprise $75 \%$ of the sugarcane farmers in Fiji, and continue to derive benefits from sugar sales to the lucrative European Union (EU) market. The EU market provides a price which is two to three times higher than the world free market price of sugar. Various studies on land ownership security (Clark, 1969; Baron, 1978; Tanabe, 1978; Tomosugi, 1980 Kemp, 1981; Feeny, 1982) have pointed out that as income potential from land increased, the incidence of land disputes and land grabbing and consequently, tenure insecurity increased. This is no different from the problem in Fiji.

With land leases coming up for renewal this year, the indigenous community are demanding their land back. The lease contract has no provision for continued renewal of the land leases. This has led to a national debate regarding appropriate land reform that not only safeguards the interest of the tenants and landlords, but also promotes efficiency and productivity of the agricultural sector.

Data from the industry reveal that significant differential in productivity exists among the various types of land tenure systems (Table 2 ). The highest yield is recorded on crown land while the lowest is on vakavanua (land given out to clan members to farm under an informal arrangement). 
Table 2: $\quad$ Cane yield, $t / h a$, by ethnicity and lease type - 1984-96

\begin{tabular}{lllll}
\hline & Fijian & Indo Fijians & Other & All races \\
\hline Freehold & 48.5 & 60.2 & 59.2 & 60.1 \\
Crown lease & 51.2 & 62.3 & 62.1 & 62.0 \\
Native lease & 49.5 & 59.5 & 43.7 & 57.4 \\
Vakavanua & 52.2 & 54.7 & 54.9 & 52.3 \\
All lease types & 50.5 & 60.3 & 52.2 & 58.4 \\
\hline
\end{tabular}

Source: FSC Grower Census Database 1993-99 as quoted in Lal et al., 2001.

\section{Tenancy Status and Efficiency}

This section investigates the productivity and efficiency of owner and tenant operated farms. The proposed modelling methodology and data are first discussed. Results from this analysis can be used to derive explicit policy implications to ensure that the industry remains economically viable.

\section{Methodology}

This paper utilises the stochastic frontier production function proposed independently by Aigner et al., (1977) and Meeusen and van den Broeck (1977) to determine the level of efficiency for male and female headed households. This model has been applied and modified in numerous studies including Battese and Corra (1977), Lee and Tyler (1978), Stevenson (1980), Pitt and Lee (1981), Jondrow et al., (1982), Kalirajan (1981), Bagi and Huang
(1983), Kalirajan and Flinn (1983), Huang and Bagi (1984), Schmidt and Sickles (1984), Waldman (1984) Coeli (1985), Battese and Coelli (1988), Battese et al., (1989) and Battese and Coelli $(1992,1993)$.

There has also been wide application of this methodology in the agricultural industries. Battese (1992), Bravo-Ureta and Pinheiro (1993) and Coelli (1995) provide surveys of applications in this field.

The stochastic frontier production function can be expressed as follows:

$$
Y_{i}=x_{i} \beta+E_{i},
$$

and

$$
\mathrm{E}_{\mathrm{i}}=\mathrm{V}_{\mathrm{i}}-\mathrm{U}_{\mathrm{i}}
$$

where $Y_{i}$ denotes output for the ith sample firm $(\mathrm{i}=1,2, \ldots, \mathrm{N}) ; \mathrm{x}_{\mathrm{i}}$ is a $(1 \mathrm{x}$ k) vector of inputs associated with ith 
sample firm; $\beta$ is a $(\mathrm{k} \times 1)$ vector of the coefficients for the associated independent variables in the production function; $\mathrm{V}_{\mathrm{it}}$ are assumed to be independent and identically distributed as $\mathrm{N}\left(\begin{array}{ll}0, & \sigma_{\mathrm{v}}^{2}\end{array}\right)$, independently distributed of $U_{i} ; U_{i}$ are non-negative, technical inefficiency effects, which are assumed to be independently and identically distributed non-negative random variables, which can follow such distributions as half normal, truncated normal, exponential and gamma distributions (Aigner et al., 1977; Greene, 1980; Meeusen and Van den Broeck, 1977).

The maximum likelihood estimation of equation (1) yields consistent estimators for $\beta, \lambda$, and $\sigma^{2}$, where $\beta$ is a vector of unknown parameters, $\lambda=\sigma_{u} / \sigma_{v}$ and $\sigma^{2}=\sigma_{u}{ }^{2}+$ $\sigma_{v}{ }^{2}$. Jondrow et al. (1982) have shown that inferences about the technical inefficiency of individual farmers can be made by considering the conditional distribution of $u$ given the fitted values of $\varepsilon$ and the respective parameters. Based on the assumptions: $\mathrm{v} \sim \mathrm{N}\left(0, \sigma_{\mathrm{v}}{ }^{2}\right), \mathrm{u} \sim \mathrm{N}(0$, $\left.\sigma_{\mathrm{u}}{ }^{2}\right)$, and $\mathrm{E}(\mathrm{v})=0$, they computed the conditional mean of $u_{i}$ given $\varepsilon_{I}=$ $\mathrm{v}_{\mathrm{i}}-\mathrm{u}_{\mathrm{i}}$ as a measure of technical efficiency as:
$E\left(u_{j} \mid \varepsilon_{j}\right)=\sigma *\left[\frac{f *\left(\varepsilon_{j} \lambda / \sigma\right)}{1-F^{*}\left(\varepsilon_{j} \lambda / \sigma\right)}-\frac{\varepsilon_{j} \lambda}{\sigma}\right]$

where $\mathrm{f}^{*}$ and $\mathrm{F}^{*}$ are, respectively, standard normal density and cumulative distributions evaluated at $\varepsilon_{i} \lambda / \sigma, \quad \sigma^{2}=\sigma_{v}^{2}+\sigma_{u}^{2}, \quad \lambda=\sigma_{u} / \sigma_{v}, \quad$ and $\sigma^{*}=\sigma_{\mathrm{u}}{ }^{2} \sigma_{\mathrm{v}}{ }^{2} / \sigma^{2}$. The estimates of $\sigma^{2}$, $\lambda$, and parameter vector $\beta$ are obtained by maximum likelihood method. Jondrow et al., (1982) also derived a similar formula for the exponential distribution while Greene (1990) derived a formula for the gamma distribution.

Replacing $\varepsilon, \sigma_{*}$, and $\lambda$ by their estimates in equation (1) and (3), we derive the estimates for $v$ and $u$. Subtracting $v$ from both sides of equation (1) yields the stochastic production frontier:

$$
\mathrm{Y}^{*}=f\left(\mathrm{X}_{i} ; \beta\right)-u=\mathrm{Y}-v,
$$

where $\mathrm{Y}^{*}$ is defined as the farm's observed output adjusted for the statistical noise contained in $\mathrm{v}$ (Bravo-Ureta and Rieger, 1991 and Bravo-Ureta and Pinheiro, 1997). Equation (4) can also be used to derive, analytically, the indirect cost function frontier. 
Empirical Model

The stochastic frontier production function for sugarcane farmers is assumed to be:

$\ln \mathrm{Y}_{\mathrm{i}}=\beta_{0}+\beta_{1} \ln \left(\mathrm{K}_{\mathrm{i}}\right)+\beta_{2} \ln \left(\operatorname{Land}_{\mathrm{i}}\right)$ $+\beta_{3} \ln \left(\mathrm{FL}_{\mathrm{i}}\right)+\beta_{4} \ln \left(\mathrm{HL}_{\mathrm{i}}\right)+\beta_{5}$ $\ln \left(\mathrm{BH}_{\mathrm{i}}\right)+\beta_{6} \ln \left(\mathrm{TH}_{\mathrm{i}}\right)+\beta_{7} \ln \left(\mathrm{FQ}_{\mathrm{i}}\right)+$ $\beta_{8} \ln \left(\mathrm{CQ}_{\mathrm{i}}\right)+\mathrm{V}_{\mathrm{i}}-\mathrm{U}_{\mathrm{i}}$

where the subscripts i refers to the ith farmer;

Ln denotes natural logarithm;

Y denotes quantity of sugarcane harvested (in tons);

$\mathrm{K}$ denotes capital (total value of farm equipment's in $\mathrm{F}$ );

L denotes land area under sugarcane crop (acres);

FL denotes total amount of family labour used (in hours);

HL denotes total amount of hired labour used (in hours);

$\mathrm{BH}$ denotes total amount of bullock labour used (in hours for a pair of bullocks);

TH denotes tractor use (in hours);

FQ denotes quantity of fertilizer applied (in number of $10 \mathrm{~kg}$ bags);

CQ denotes quantity of pesticide used (in number of 4 litre containers);
$\mathrm{V}_{\mathrm{i}}$ is assumed to be independently distributed, normal random variable, with mean, zero. The variance, $\sigma_{\mathrm{v}}^{2}$, is independently distributed of $U_{i}$ and $U_{i}$ is nonnegative technical inefficiency effects. $U_{i}$ is assumed to be independently distributed and arise from the truncation (at zero) of the normal distribution with variance, $\sigma^{2}$, and mean, $\mu_{\mathrm{i}}$. The Cobb-Douglas functional form was chosen since a more general functional form like the translog model, may be difficult to estimate due to the large number of explanatory variables examined in this study. Studies on the impact of functional form on efficiency estimates such as Kopp and Smith (1980) conclude that functional specification has very little impact on the estimated efficiency.

The $\beta$ and $\delta$ coefficients are unknown parameters to be estimated, together with variance parameters which are expressed in terms of

$$
\begin{gathered}
\sigma_{\mathrm{s}}{ }^{2}=\sigma_{\mathrm{v}}{ }^{2}+\sigma^{2} \text { and } \\
\gamma=\sigma^{2} / \sigma_{\mathrm{s}}{ }^{2}
\end{gathered}
$$

where the parameters have values between zero and one.

$\mathrm{V}_{\mathrm{i}}$ are assumed to be independently distributed normal random variables with mean, zero, and variance, $\sigma_{\mathrm{v}}^{2}$, independently distributed of $\mathrm{U}_{\mathrm{i}} ; \mathrm{U}_{\mathrm{i}}$ are non-negative 
technical inefficiency effects, which are assumed to be independently distributed and arise from the truncation (at zero) of the normal distribution with variance, $\sigma^{2}$, and mean, $\mu_{\mathrm{i}}$ defined by

$\mu_{\mathrm{i}}=\delta_{0}+\delta_{1}\left(\mathrm{AG}_{\mathrm{i}}\right)+\delta_{2}\left(\mathrm{SY}_{\mathrm{i}}\right)+$ $\delta_{3}\left(\mathrm{FST}_{\mathrm{i}}\right)+\delta_{4}\left(\mathrm{LC}_{\mathrm{i}}\right)+\delta_{5}\left(\mathrm{FS}_{\mathrm{i}}\right)$

where:

AG denotes the age of primary decision-maker (in years);

SY denotes the maximum years of formal schooling of the primary decision maker;

FST denotes farming status (dummy variable used, 1 if full time and 0 if part time);

LC denotes land class; 0 for $\mathrm{f}^{\mathrm{t}}$ class arable, 1 for $2^{\text {nd }}$ class arable, 2 for $3^{\text {rd }}$ class arable and 3 for marginal arable ${ }^{1}$;

FS farm size measured in acres

A priori, the signs of all production function parameters specified above are expected to be positive. With regard to the inefficiency model, all variables except the land class variable are expected to have a negative sign. Generally, a negative sign with respect to age implies that with increasing age, farmers become more experienced and thus become more efficient. The education variable's negative sign implies that higher education will lead to a more efficient resource allocation and thus an increase in efficiency. The land class variable is divided into 4 classes with class 1 designating the most arable land while class 4 being the poorest land. In this case, the expected sign of this variable is positive. Farm size variable is expected to have a negative sign indicating that as farm size increases, inefficiency will decline.

The inefficiency model can only be estimated if the inefficiency effects are stochastic and have a particular distributional specification. Therefore the null hypothesis that the inefficiency effects are not stochastic (Ho: $\gamma=0$ ) will be tested. Furthermore, the null hypothesis that the coefficients of the variables in the

$1^{\text {st }}$ Class arable: flat, very few limitations, suited to a wide range of crops. Improvement not needed.

$2^{\text {nd }}$ Class arable: flat to gentle slopes, moderate limitations, similar to $\mathrm{f}^{\mathrm{t}}$ class arable.

$3^{\text {rd }}$ Class arable: moderately steep, severe limitations, suited to a narrow range of crops. Improvements required.

Marginal arable: steep slopes, very severe limitations. Major improvements required. 
model for the inefficiency effects are zero $\left(\mathrm{H}_{0}: \delta_{1}=\ldots=\delta_{4}=0\right)$ will also be tested. These null hypothesis are tested using the generalised likelihood-ratio statistic, $\lambda$, defined by:

$$
\lambda=-2 \ln \left[\mathrm{L}\left(\mathrm{H}_{0}\right) / \mathrm{L}\left(\mathrm{H}_{1}\right)\right]
$$

where $\mathrm{L}\left(\mathrm{H}_{0}\right)$ and $\mathrm{L}\left(\mathrm{H}_{1}\right)$ are values of the likelihood function under the specifications of the null and alternative hypothesis, $\mathrm{H}_{0}$ and $\mathrm{H}_{1}$.

\section{Data}

The data for this study were obtained from a survey carried out over a 9 week period (December 23, 1996 to February 22, 1997). A stratified random sampling approach was used to collect the data where the strata's included the two ethnic communities and the different farm sizes. Detail discussion on sampling design, sample size and data collection are provided in Reddy (1998).

\section{Results and Discussion}

Data on input usage and output differential by ownership status are presented in Table 3. Tenant and owner operated farms show a per acre output difference of approximately 3 tons in favour of the owner operated farms. Large difference in input usage were observed for labour, capital and bullock hours. The lower amount of capital usage on tenant farms supports the hypothesis that tenant farmers feel insecure about making major farm investments. Therefore, wherever possible, manual family labour is substituted. However, due to a large variation observed for individual variables, the means t-test at 5\% level of significance provides no significant level of difference among the two farm ownership types.

Results of the efficiency analysis are presented in Table 4 below. The estimated parameters of the production function confirm to a priori expectations. Both models have a good fit with 4 variables being significantly different from zero in the first model and 6 variables significantly differently from zero in the second model. The $\gamma$ parameter is close to 1.0. This implies that the technical inefficiency effects are significant in the stochastic frontier model and that the traditional production function, with no technical inefficiency effects is not an adequate representation of the data. The mean technical efficiency of the tenant farms are $82.3 \%$ while the owner operated farms operate at 90.3\% efficiency. As outlined in the earlier section, lack of investor confidence is one of the reasons why this result is observed. Investments 
which may provide return in the longer run period may not be made due to uncertainty over the renewal of farm leases.

The efficiency differential between the farm types implies that if tenant farms increase their efficiency to the level of the owner operated farms (an increase of $8 \%$ ), then the tenant farms can increase their per acre output by approximately 2.1 tons. This implies that for an average farmer, cultivating 9.33 acres of land with sugarcane (Reddy, 1998), based on a per ton price of $\$ 49$, a net gain of $\$ 960.05$ can be made if an efficiency increase by $8 \%$ is made. This is a substantial amount of monetary gain for small farmers.

Table 3: $\quad$ Productivity and input usage differential by ownership status

\begin{tabular}{lcc}
\hline Variables & Tenant Farmers & Owner Farmers \\
\hline $\mathrm{Y}$ & 21.676 & 24.281 \\
& $(60,190)$ & $(55,226)$ \\
$\mathrm{K}$ & 277.908 & 384.734 \\
& $(22,929,964)$ & $(27,052,225)$ \\
$\mathrm{FL}$ & 31.139 & 37.088 \\
& $(75,976)$ & $(79,635)$ \\
$\mathrm{HL}$ & 20.099 & 14.047 \\
& $(237,312)$ & $(120,832)$ \\
$\mathrm{BH}$ & 9.525 & 13.565 \\
& $(11,488)$ & $(11,500)$ \\
$\mathrm{TH}$ & 3.281 & 3.508 \\
& $(13,188)$ & $(11,170)$ \\
$\mathrm{FQ}$ & 5.687 & 5.991 \\
& $(4,921)$ & $(2,826)$ \\
$\mathrm{CQ}$ & 0.302 & 0.311 \\
& $(15)$ & $(13)$ \\
\hline
\end{tabular}

Note: 1) Figures in parenthesis are variance estimates.

2) Units of measurement for each variable: $Y=$ quantity of sugarcane harvested in tons; $\mathrm{K}=$ total value of farm implements in $\mathrm{F} \$ \mathrm{FL}=$ family labour in hrs; $\mathrm{HL}=$ hired labour in hrs; $\mathrm{BH}=$ Bullocks use in hrs; $\mathrm{TH}=$ tractor use in hrs; $\mathrm{FQ}=$ fertiliser use in $10 \mathrm{~kg}$ bags; and $\mathrm{CQ}=$ Pesticide chemicals used in 4 litre containers. 
The inefficiency model reveals that farming status significantly adds to the level of efficiency experienced by the farms. Both the tenant farms and the owner-operated farms reveal a negative coefficient of the "Farming Status" variable. This implies that the part-time farms are associated with higher level of inefficiency compared to full-time farmers. The other variables do not affect the variation in farm efficiency significantly.

Table 4: Maximum-likelihood estimates for parameters of the Stochastic Frontiers and Inefficiency Models for sugarcane farmers in Fiji

\begin{tabular}{lccc}
\hline Variable & Parameter & Tenant Farms & Owner Farms \\
\hline Constant & $\beta_{0}$ & $1.29^{*}$ & $1.412^{*}$ \\
& & $(0.141)$ & $(0.084)$ \\
Capital & $\beta_{1}$ & $0.061^{*}$ & $0.041^{*}$ \\
& & $(0.009)$ & $(0.012)$ \\
Land & $\beta_{2}$ & $0.615^{*}$ & $0.645^{*}$ \\
& & $(0.057)$ & $(0.062)$ \\
Family labour & $\beta_{3}$ & 0.004 & 0.008 \\
& & $(0.086)$ & $(0.032)$ \\
Hired labour & $\beta_{4}$ & 0.021 & $0.031^{*}$ \\
& & $(0.026)$ & $(0.015)$ \\
Bullock hours & $\beta_{5}$ & 0.047 & $0.057^{*}$ \\
& & $(0.032)$ & $(0.021)$ \\
Tractor hours & $\beta_{6}$ & $0.037^{*}$ & $0.046^{*}$ \\
& & $(0.017)$ & $(0.017)$ \\
Fertiliser quantity & $\beta_{7}$ & $0.154^{*}$ & 0.020 \\
& & $(0.031)$ & $(0.033)$ \\
Chemical quantity & $\beta_{8}$ & 0.009 & $0.065^{*}$ \\
& & $(0.031)$ & $(0.028)$ \\
Inefficiency Model & & 0.132 & 0.145 \\
Constant & & $(0.135)$ & $(0.154)$ \\
& & 0.003 & 0.002 \\
Age & & $(0.001)$ & $(0.001)$ \\
Education & & -0.002 & -0.016 \\
& & $(0.004)$ & $(0.003)$ \\
\hline
\end{tabular}


Contd. Table 4: Maximum-likelihood estimates for parameters of the Stochastic Frontiers and Inefficiency Models for sugarcane farmers in Fiji ${ }^{\mathrm{a}}$

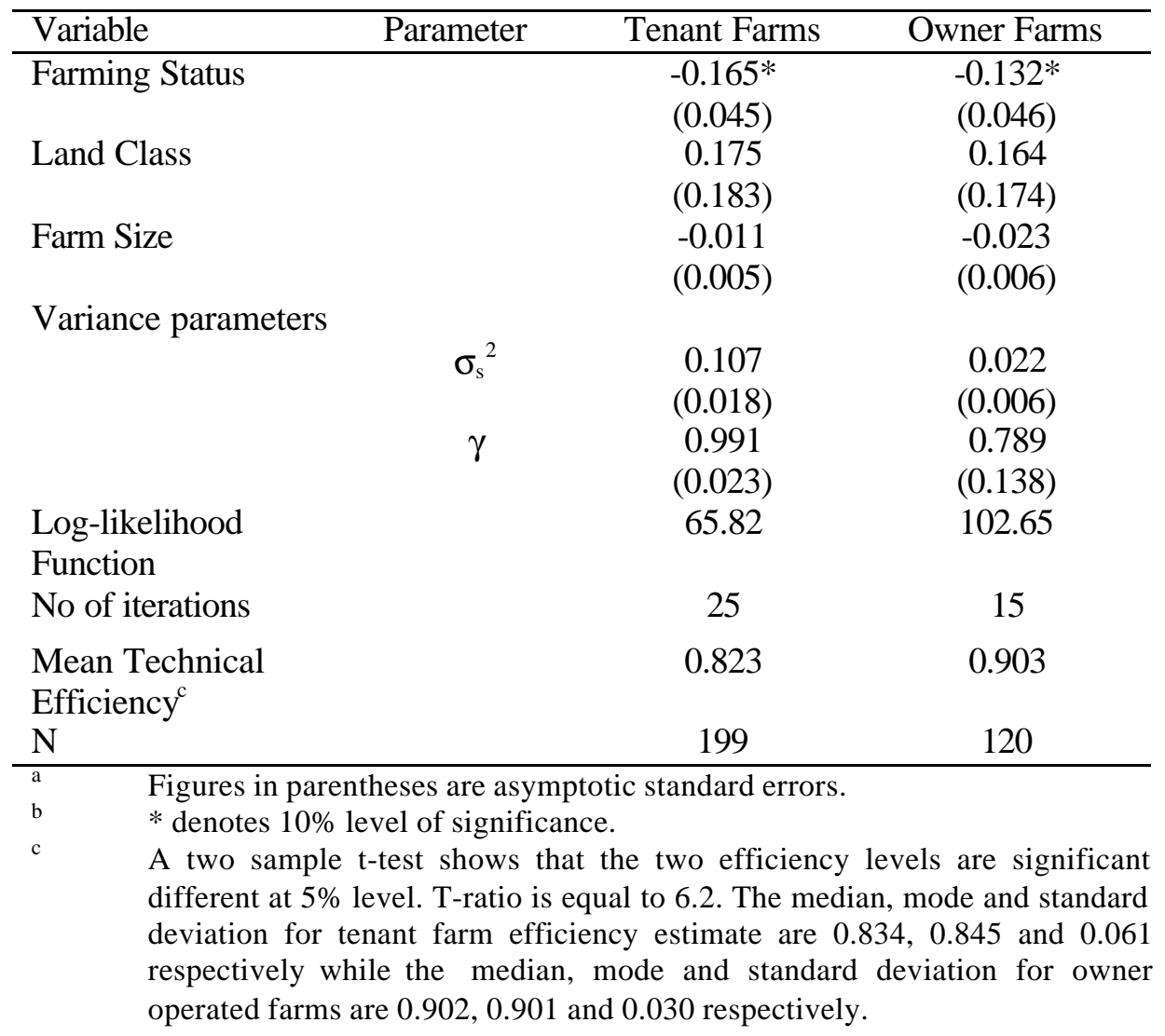

Summary and Policy Implication

This study has examined the issue of productivity and efficiency differentials between leased farms and owner operated farms utilising the stochastic frontier function methodology. Previous studies have examined these differences using traditional methods and thus were unable to estimate the exact level of efficiency difference. Data used in this study were obtained from a farm level survey of Fiji's sugarcane farmers in January/February 1997.

Results from the study indicate a substantial difference between 
productivity and efficiency for these two types of farms. Tenant operated farms have a substantially lower efficiency and productivity than owner operated farms. One of the key reasons for such a result is the lack of security which inhibits any long-term investments on farm by farmers operating on leased land. This is an example of how markets fail to allocate resources efficiently when some of the prerequisites for the market to function efficiently are not fulfilled.

The problem of lack of illdefined property rights is not only a hindrance to increased efficiency and productivity in the agriculture sector, but also to other sectors of the economy where it depresses investor confidence. Well defined property rights, which require markets to function properly, should have the characteristics of universality, exclusivity, transferability and enforceability (Posner, 1972; Randall, 1987 and Tietenberg, 1992).

The industry also has a large number of farmers who farm the land on a part-time basis. These are marginal farms who supply poor quality cane which affects the returns that accrue to other farmers also. Given the competitive stage that the industry is in, part-time farmers may have to be asked to wind up cane farming.
It is recommended that the land market in Fiji be subject to gradual deregulation if the agricultural sector is required to play a significant role in the growth and development of the Fijian economy. Given the importance of agriculture in Fiji's economy, the failure of this sector will have serious negative general equilibrium impacts.

\section{References}

Aigner, D., C.A.K. Lovell and P. Schmidt (1977). Formulation and Estimation of Stochastic Frontier Production Function Models. Journal of Econometrics, 6(2):21-37.

Atwood, D.A. (1990). Land Registration in Africa: The Impact on Agricultural Production, World Development, 18:659-671.

Bagi, F.S. and C.J. Huang (1983). Estimating Production Technical Efficiency for Individual Farms in Tennessee. Canadian Journal of Agricultural Economics. 31(1):249-256.

Baron, D. (1978). Land Reform in Sub-Saharan Africa: An Annotated Bibliography, Office of Rural Development, U.S. Agency 
$\begin{array}{ll}\text { for } & \text { International } \\ \text { Development, } & \text { Washington, }\end{array}$ DC.

Barrows, R., and M. Roth (1990). Land Tenure and Investment in African Agriculture: Theory and Evidence. Journal of Modern African Studies, 28:265-297.

Battese, G.E. (1992). Frontier Production Functions and Technical Efficiency: A Survey of Empirical Applications in Agricultural Economics. Agricultural Economics, 7(2):185-208.

Battese, G.E. and G.S. Corra (1977). Estimation of a Production Frontier Model: With Application to the Pastoral Zone of Eastern Australia. Australian Journal of Agricultural Economics, 21(1):169-179.

Battese, G.E. and T.J. Coelli (1993). A Stochastic Frontier Production Function Incorporating a Model for Technical Inefficiency Effects. Working Papers in Econometrics and Applied Statistics, No. 69, Department of Econometrics, University of New England, Armidale.
Battese, G.E. and T. J. Coelli (1992). Frontier Production Functions Technical Efficiency and Panel Data: with Application to Paddy Farmers in India. Journal of Productivity Analysis, 3(1):153-169.

Battese, G.E. and T. J. Coelli (1988). Prediction of Firm-level Technical Efficiencies with a Generalised Frontier Production Function and Panel Data. Journal of Econometrics, 38:387-399.

Battese, G.E., T. J. Coelli and T.C. Colby (1989). Estimation of Frontier Production Functions and the Efficiencies of Indian Farms Using Panel Data from ICRISAT's Village Level Studies. Journal of Quantitative Economics, 5(1):327-348.

Bravo-Ureta, B.E, and A.E. Pinheiro (1993). Efficiency Analysis of Developing Country Agriculture: A Review of the Frontier Function Literature. Agricultural and Resource Economics Review, 22:88101.

Bravo-Ureta, B.E. and A.E. Pinherio (1997). Technical, 
Economic, and Allocative Efficiency in Peasant Farming: Evidence from the Dominican Republic. Developing Economies, 34:48-67.

Bravo-Ureta, B.E, and L. Rieger (1991). Dairy Farm Efficiency Measurement Using Stochastic Frontiers and Neoclassical Duality. American Journal of Agriculture Economics, 73:421-28.

Bruce, J.W. and S.E. Migot-Adolla (1994). Searching for Land Tenure Security in Africa: Review. Kendall-Hunt Publishing Company, Dubuque IA.

Clark, R.J. (1969). Problems and Conflicts over Land Ownership in Bolivia. Land Tenure Center, Reprint No. 54-55, University of Wisconsin, Madison.

Coelli, T.J. (1992). A Computer Program for Frontier Production Function Estimation: FRONTIER, Version 4.1. Department of Econometrics, University of New England.
Coelli, T.J. (1995). Recent Developments in Frontier Estimation and Efficiency Measurement. Australian Journal of Agricultural Economics, 39(1):219-245.

Feder, G. (1987). Land Ownership Security and Farm Productivity: Evidence from Thailand. Journal of Development Studies, 24:1629.

Feder, G., and T. Onchan (1987). Land Ownership Security and Farm Investment. American Journal of Agricultural Economics, 69:311-320.

Feeny, D. (1982). The Political Economy of Productivity: Thai Agricultural Development 1880-1975. Vancouver: University of British Columbia Press.

Gavin, S., and M. Fafchamps (1996). Land Tenure and Allocative Efficiency in Niger. American Journal of Agricultural Economics, 78:460-471.

Green, J.K. (1987). Evaluating the Impact of Consolidating Holdings, Individualisation of Tenure, and Registration 
of Title: Lessons from Kenya," Land Tenure Centre Paper \# 129, University of Wisconsin, Madison.

Greene, W.H. (1990). A GammaDistributed Stochastic Frontier Model. Journal of Econometrics, 46(2):141163.

Greene, W.H. (1980). Maximum Likelihood Estimation of Econometric Frontier Functions. Journal of Econometrics, 13(2):27-56.

Huang, C.J. and F.S. Bagi (1984). Technical Efficiency on Individual Farms in Northwest India. Southern Economic Journal, 51(1):108-115.

Jondrow, J., C.A.K. Lovell, I.S. Materov and P. Schmidt (1982). On the Estimation of Technical Inefficiency in the Stochastic Frontier Production Function Model. Journal of Econometrics, 19(2):233-238.

Kalirajan, K.P. (1981). An Econometric Analysis of Yield Variability in Paddy Production. Canadian Journal of Agricultural Economics, 29(2): 283-294.
Kalirajan, K.P. and J.C. Flinn (1983). The Measurement of Farm Specific Technical Efficiency. Pakistan Journal of Applied Economics, 2(1):167-180.

Kemp, J. (1981). Legal and Informal Land Tenures in Thailand. Modern Asian Studies, 15(2):1-23.

Kille, G.S., and M.C. Lyne (1993). Property Rights to Land, OnFarm Investment and Farm Productivity: A Study of KwaZulu, South Africa, Mimeo, University of Natal, Pietermaritzberg, South Africa.

Kopp, R.J. and V.K. Smith. (1980). Frontier Production Function Estimates for Steam Electric Generation: A Comparative Analysis. Southern Economics Journal, 47(1):1049-1059.

Lal, P, H. Lim-Applegate and M. Reddy (2001). Land Tenure Dilemma in Fiji-can Fijian Landowners and Indo-Fijian Tenants have their Cake and Eat it too? Pacific Economic Bulletin 16(2):10-15.

Lee, L.F. and W.G. Tyler (1978). A Stochastic Frontier 
Production Function and Average Efficiency: An Empirical Analysis. Journal of Econometrics, 7(2):385390.

Meeusen, W. and J. van den Broeck (1977).

Efficiency Estimation from CobbDouglas Production Functions with Composed Error. International Economic Review, 18(1): 435-444.

Pitt, M.M. and L.F. Lee (1981). Measurement and Sources of Technical Inefficiency in the Indonesian Weaving Industry. Journal of Development Economics, $9(1): 43-64$.

Posner, R.A. (1972). Economic Analysis of Law. Boston: Little Brown.

Randall, A. (1987). Resource Economics. New York: John Wiley and Son.

Reddy, M. (1998). Production Economics Analysis of Fiji's Sugar Industry. Unpublished Ph.D Dissertation, University of Hawaii.
Salas, O., F. Knight and C. Saenz (1970). Land Tilting in Costa Rica: A Legal and Economic Survey, University of Costa Rica Law School, San Jose.

Schmidt, P. and R.C. Sickles (1984). Production Frontiers and Panel Data. Journal of Business and Economic Statistics, 2(1):367-374.

Stevenson, R.E. (1980). Likelihood Functions for Generalised Stochastic Frontier Estimation. Journal of Econometrics, 13(2):57-66.

Tanabe, S. (1978). Land Reclamation in the Chao Phraya Delta. In, Y. Ishii (ed.), Thailand: A Rice Growing Society (trans. By P. Hawkes and S.Hawakes), Honolulu: University Press of Hawaii.

Tietenberg, T.H. (1992). Environmental and Natural Resource Economics. USA: Harper Collins Publishers Inc.

Tomosugi, T. (1980). A Structural Analysis of Thai Economic History: A Case Study of a Northern Chao Phraya Delta Village, Institute for Developing Economies, Tokyo. 
Villamizar, F. (1984). IBD Financing in Land Administration Programs. Paper Presented at the International Workshop on Land Tenure Administration, Salvador, Brazil, August, pp. 22-24.
Waldman, D.M. (1984). Properties of Technical Efficiency Estimators in the Stochastic Frontier Model. Journal of Econometrics, 25(1):353364. 